\title{
IMPLEMENTASI KURSUS PRA NIKAH DALAM MENGURANGI ANGKA PERCERAIAN DI KUA PRINGSEWU
}

\author{
Afrizal \\ Pegawai KUA Pegelaran Kabupaten Pringsewu \\ Provinsi Lampung \\ email: afrizal@yahoo.co.id \\ Diterima: 02 Desember 2016. Disetujui: 08 April 2017 \\ Dipublikasikan: Mei 2017
}

\begin{abstract}
In Pringsewu district, divorce rates are still high. Since 2013, there were 80 divorce cases, in 2014, 89 and in 2015, 6380 divorce cases. Preservation of a marriage is not only sought after the occurrence of problems in the household, but it need before the wedding. Based on the Decree of the Director General of Islamic Guidance No. DJ.II / 542 of 2013, the Pre-Marriage Course conducted by BP4 for the bride and groom. This article describe the implementation of PreMarriage Courses in Pringsewu District KUA and its impact in reducing divorce rates. The conduct of Pre-Marriage Courses is still lacking or not optimal; either in terms of institutions, executors or resource persons, pre-facilities, financing, participants, and course materials. Pre-Marriage Course Policy has a stake in reducing the divorce rate, and encouraging the establishment of a sakinah family in the area
\end{abstract}

Keywords: Kursus Pra Nikah, Kecamatan Pringsewu, BP4 


\section{A. Pendahuluan}

Perceraian memang halal, namun Allah sangat membencinya. bahkan Rasulullah pernah menyatakan istriistri yang meminta cerai kepada suaminya tanpa alasan yang dibenarkan dia tidak akan mencium bau surga. Hal ini sebagaimana sabda Nabi Muhammad saw:

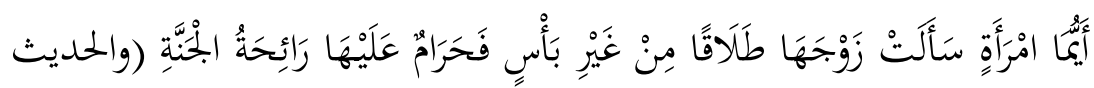

$$
\begin{aligned}
& \text { صححه الألباني في صحيح الترمذي) }
\end{aligned}
$$

Artinya:

Wanita mana saja yang meminta kepada suaminya perceraian tanpa alasan (kuat). Maka dia diharamkan mencium bau surga. (Hadis dishahihkan Al-Albany di Shahih Tirmizi) ${ }^{1}$

Karena itu pulalah pemerintah Indonesia merumuskan perundang-undanganan yang mempersulit terjadinya perceraian dan membentuk badan penasehat perkawinan atau lebih dikenal BP4 (Badan Penasihatan, Pembinaan, dan Pelestarian Perkawinan). Pelestarian sebuah pernikahan tidak hanya diupayakan setelah terjadinya masalah dalam rumah tangga. Namun pelestarian sebuah pernikahan haruslah diupayakan sejak sebelum terjadinya pernikahan. Dengan keluarnya Surat Keputusan Dirjen Bimas Islam Nomor DJ.II/542 Tahun 2013 tentang Pedoman Penyelenggaraan Kursus Pra Nikah, pemerintah mengamanatkan agar sebelum pernikahan dilangsungkan, setiap calon pengantin harus diberikan wawasan terlebih dahulu tentang arti sebuah rumah tangga melalui Kursus Pra Nikah. Surat edaran ini juga merupakan respon dari tingginya angka perceraian dan kasus KDRT (Kekerasan Dalam Rumah Tangga) di Indonesia. Dengan mengikuti Kursus Pra Nikah pasangan calon

${ }^{1}$ Abd Rahman Ghazaly, Fikih munakahat, Jakarta: Kencana Prenada Media Grup, 2003), h. 213 
pengantin yang mau melenggang ke jenjang pernikahan akan dibekali materi dasar pengetahuan dan ketrampilan dalam kehidupan berumah tangga.

Di KUA yang berada di Kecamatan Pringsewu Program kegiatan Kursus Pra Nikah ini diselenggarakan bukan dalam waktu 24 jam sebagaimana aturan edaran dirjen tentang Kursus Pra Nikah. Hal ini karena belum tersedianya dana yang memadai untuk kegiatan Kursus Pra Nikah dari anggaran Kementerian Agama. Tetapi dilaksanakan maksimal sampai tiga jam saja, setiap hari Senin, Selasa, Rabu dan Kamis, dimulai pada pukul 09.00 WIB bertempat di ruangan kerja staf dan diikuti oleh peserta calon-calon pengantin yang sudah terdaftar sejak 10 hari sebelum pelaksanaan akad nikah masing-masing pengantin dilaksanakan.

Dengan waktu pelaksanaan yang sesingkat itu tentu tujuan dari diterbitkannya peraturan tentang Kursus Pra Nikah ini belum dapat mencapai maksud dan tujuan yang diharapkan. Dari latar belakang tersebut di atas, penulis tertarik untuk meneliti lebih lanjut bagaimana implementasi penyelenggaraan Kursus Pra Nikah di KUA Kecamatan Pringsewu ? dan Bagaimana dampak dari penyelenggaraan Kursus Pra Nikah dalam mewujudkan keluarga sakinah di KUA Kecamatan Pringsewu?

\section{B. Pembahasan}

\section{Pengertian Kursus Pra Nikah}

Pengertian kursus secara Etimologi dijelaskan dalam Kamus Besar Bahasa Indonesia adalah pelajaran tentang suatu pengetahuan atau keterampilan, yang diberikan dalam waktu singkat. ${ }^{2}$ Pengertian kata Pra adalah bentuk terikat yang berarti sebelum; di depan. ${ }^{3}$ Kata nikah Nikah secara Etimologi adalah ikatan (akad) perkawinan yang dilakukan

${ }^{2}$ Tim Redaksi Kamus Pusat bahasa, Kamus Besar Bahasa Indonesia, (Jakarta: Balai Pustaka, 2007), h. 617

3Ibid, h. 891 
sesuai dengan ketentuan hukum dan ajaran agama. ${ }^{4}$

Sedangkan pengertian Kursus Pra Nikah secata Termininologi menurut Perdirjen Bimas Islam Nomor DJ.II/542 Tahun 2013 tentang Pedoman Penyelenggaraan Kursus Pra Nikah adalah pemberian bekal pengetahuan, pemahaman, keterampilan, dan penumbuhan kesadaran kepada remaja usia nikah tentang kehidupan rumah tangga dan keluarga. ${ }^{5}$

Kursus Pra Nikah merupakan bimbingan kepada calon pengantin (calon suami istri) sebagai bekal pengetahuan untuk mengarungi bahtera rumah tangga yang diberikan oleh petugas BP4 dalam hal pemberian materi bimbingan sebagai bekal kehidupan pernikahan, kesehatan keluarga, dan lainnya. Dengan pemberian materi tersebut diharapkan dapat meningkatkan kualitas keluarga atau meraih kehidupan rumah tangga yang diidam-idamkan oleh para pasangan calon pengantin, yaitu mencapai keluarga yang sakinah, mawaddah, wa rahmah.

\section{Dasar Hukum Kursus Pra Nikah}

Pemerintah Indonesia merumuskan perundangundangan yang mempersulit terjadinya perceraian dan membentuk badan penasehatan perkawinan atau yang lebih dikenal dengan nama BP4. BP4 adalah satu-satunya badan yang berusaha di bidang penasihatan perkawinan dan pengurangan perceraian. Fungsi dan Tugas BP4 tetap konsisten melaksanakan UU No. 1 tahun 1974 tentang Perkawinan dan Peraturan Perundang-undangan lainnya tentang Perkawianan. Oleh karenanya fungsi dan peranan BP4 sangat diperlukan masyarakat dalam mewujudkan kualitas perkawinan.

Dalam Undang-Undang Nomor 1 Tahun 1974 tentang

${ }^{4}$ Ibid, h. 782

5Peraturan Direktur Jenderal Bimbingan Masyarakat Islam Nomor DJ.II/542 TAHUN 2013 tentang Pedoman Penyelenggaraan Kursus Pra Nikah, Jakarta, 2013, h. 2 
Perkawinan, pasal 1 disebutkan: Perkawinan adalah ikatan lahir batin antara seorang pria dengan seorang wanita sebagai suami isteri dengan tujuan membentuk keluarga (rumah tangga) yang bahagia dan kekal berdasarkan Ketuhanan Yang Maha Esa, untuk membina dan terciptanya suatu rumah tangga yang sakinah, mawaddah, dan rahmah.

Pelestarian sebuah pernikahan tidak hanya diupayakan setelah terjadinya masalah dalam rumah tangga. Namun pelestarian sebuah pernikahan haruslah diupayakan sedini mungkin, yaitu sejak sebelum terjadi atau dilangsungkannya pernikahan tersebut. Melalui Keputusan Menteri Agama (KMA) No.477 Tahun 2004, pemerintah mengamanatkan agar sebelum pernikahan dilangsungkan, setiap calon pengantin harus diberikan wawasan terlebih dahulu tentang arti sebuah rumah tangga melalui Kursus Pra Nikah.

Dengan keluarnya Surat Edaran Dirjen Bimas Islam Nomor: DJ.II/542 tahun 2013 membuat gerak langkah kursus Pra Nikah semakin jelas, ditambah dengan Surat Edaran Menteri Dalam Negeri Nomor 400/54/III/Bangda perihal Pelaksanaan Pembinaan Gerakan Keluarga Sakinah, lahirnya peraturan-peraturan tentang kursus pra nikah tersebut, merupakan bentuk kepedulian nyata Pemerintah terhadap tingginya angka perceraian dan kasus KDRT (kekerasan dalam rumah tangga) di Indonesia. Diharapkan dengan dimasukkannya Kursus Pra Nikah sebagai salah satu syarat atau prosedur sebelum dilangsungkannya pernikahan, maka pasangan calon pengantin selayaknya sudah memiliki wawasan dan bekal ilmu seputar kehidupan rumah tangga yang pada gilirannya akan mampu secara bertahap mengurangi dan meminimalisir angka perceraian dan kekerasan dalam rumah tangga di Indonesia.

\section{Tujuan Kursus Pra Nikah}

Pada Bab II Pasal 2 Peraturan Direktur Jendral Bimbingan Masyarakat Islam Kementerian Agama Nomor DJ.II/372 Tahun 2011 Tentang Pedoman Penyelenggaraan 
Kursus Pra Nikah menjelaskan bahwa tujuan Kursus Pra Nikah adalah untuk meningkatkan pemahaman dan pengetahuan tentang kehidupan rumah tangga/keluarga dalam mewujudkan keluarga sakinah, mawaddah, wa rahmah serta mengurangi angka perselisihan, perceraian, dan kekerasan dalam rumah tangga. ${ }^{6}$

Dalam Peraturan Dirjen Bimas Islam Nomor DJ.II/542 Tahun 2013 disebutkan tujuan kursus pra nikah Antara lain:

a. Tujuan Umum :

Mewujudkan keluarga yang sakinah, mawaddah, wa rahmah melalui pemberian bekal pengetahuan, peningkatan pemahaman dan ketrampilan tentang kehidupan rumah tangga dan keluarga.

b. Tujuan khusus :

1) Untuk menyamakan persepsi badan/lembaga penyelenggara tentang substansi dan mekanisme penyelenggaraan kursus pra nikah bagi remaja usia nikah dan calon pengantin;

2) Terwujudnya pedoman penyelenggaran kursus pra nikah bagi remaja usia nikah dan calon pengantin; ${ }^{7}$

Berdasarkan apa yang telah di paparkan di atas, dapat dilihat bahwa tujuan dari Kursus Pra Nikah adalah memberikan pengetahuan, pemahaman, keterampilan, dan penumbuhan kesadaran tentang seputar permasalahan pernikahan dan permasalahan kehidupan rumah tangga dan keluarga bagi para calon pasangan suami istri.

Kursus Pra Nikah ini dilaksanakan oleh BP4. Berdasarkan MUNAS BP4 ke XIV/2009 di Jakarta pada 1-3

${ }^{6}$ Peraturan Direktur Jendral Bimbingan Masyarakat Islam Kementerian Agama Nomor DJ.II/372 Tahun 2013 Tentang Pedoman Penyelenggaraan Kurus Pra Nikah, h. 4

${ }^{7}$ Peraturan Direktur Jendral Bimbingan Masyarakat Islam Kementrian Agama Nomor DJ.II/372 Tahun 2013 Tentang Pedoman Penyelenggaraan Kurus Pra Nikah, h. 7 
Juni 2009 yang dipimpin oleh ketua sidangnya Moh. Muchtar Ilyas dan sekretaris sidang Najib Anwar, menegaskan kembali pada pasal 1 bahwa BP4 adalah Badan Penasehatan, Pembinaan dan Pelestarian Perkawinan. Dan pada pasal 6 salah satu upaya dan usaha BP4 adalah memberikan bimbingan, nasehat dan penerangan mengenai nikah, talak, cerai, dan rujuk kepada masyarakat baik perorangan maupun kelompok. ${ }^{8}$

\section{Komponen-Komponen Kursus Pra Nikah}

Peraturan Dirjen Bimas Islam Kemenag. RI No. DJ.II/491/2009 juncto Perdirjen Bimas Islam Nomor DJ.II/372/2011 tentang Kursus Calon Pengantin. Dan Perdirjen Bimas Islam No Dj.II/542 tahun 2013 tentang Penyelenggaraan Kursus Pra Nikah. Dalam aturan tersebut, materi Kursus Pra Nikah telah distandarisasikan dengan 7 materi selama 24 jam pelajaran, dengan rincian sebagai berikut:
a. Tata cara dan prosedur perkawinan 2 jam pelajaran.
b. Pengetahuan Agama 5 jam pelajaran.
c. Peraturan Perundang-undangan di bidang perkawinan dan keluarga 4 jam pelajaran.
d. Hak dan kewajiban suami istri 3 jam pelajaran.
e. Kesehatan reproduksi 3 jam pelajaran.
f. Managemen keluarga 3 jam pelajaran.
g. Psikologi perkawinan dan keluarga 2 jam pelajaran.

Sedang narasumber terdiri dari konsultan perkawinan dan keluarga sesuai keahlian yang dimiliki mere masingmasing. Adapun metode yang digunakan dalam pelaksanaan kursus in adalah dengan metode ceramah, dialog, simulasi, dan studi kasus (Perdirjen Bimas Islam No DJ.II/542 /2013 Pasal 8).

Dalam pelaksanaan bimbingan pra nikah, salah satu unsur yang paling pokok adalah subjek (pembimbing, tutor,

${ }^{8}$ Hasil Putusan MUNAS BP4 ke XIV/2009, Jakarta, 1-3 Juni 2009, h. 5 
konsultan perkawinan dan keluarga) sebagai narasumber ataupun pasilitator dalam pelaksanaan kursus tersebut. Pembimbing atau tutor harus mampu membaca situasi dan kondisi calon pengantin yang dihadapi dan menguasai bahan atau materi serta dapat memberi contoh atau teladan yang baik.

Sesuai ketentuan pasal 3 ayat (1): bahwa penyelenggara Kursus Pra Nikah adalah Badan Penasihatan, Pembinaan, dan Pelestarian Perkawinan (BP4) atau lembaga/organisasi keagamaan Islam lainnya sebagai penyelenggara kursus pra nikah yang telah mendapat Akreditasi dari Kementerian Agama.

Dengan ketentuan ini maka penyelenggaraan kursus pra nikah dapat dilaksanakan oleh badan/lembaga di luar instansi pemerintah dalam hal ini KUA kecamatan, tetapi pelaksanaannya dilakukan oleh badan/lembaga/organisasi keagamaan Islam yang telah memenuhi ketentuan yang di tetapkan oleh Pemerintah. Pemerintah dalam hal ini adalah Kementerian Agama berfungsi sebagai regulator, pembina, dan pengawas. Berbeda pelaksanaannya dengan kursus calon pengantin yang dilakukan pada waktu yang lalu dilaksanakan langsung oleh KUA/BP4 kecamatan. Penyelenggaraan Kursus Pra Nikah sebagaimana diatur dalam pedoman ini memberi kesempatan yang luas kepada masyarakat untuk ikut serta berpartisipasi dalam pembinaan dan pembangunan keluarga serta mengurangi angka perceraian dan kekerasan dalam keluarga.

Penyelenggara yang berwenang terhadap pelaksanaan Kursus Pra Nikah adalah Badan Penasehatan, Pembinaan, dan Pelestarian Perkawinan (BP4) atau badan dan lembaga lain yang telah mendapat Akreditasi dari Kementerian Agama (Perdirjen Bimas Islam No DJ.II/542 /2013 pasal 3). Dalam aturan tersebut juga diatur tentang Sertifikasi. Bahwa calon pengantin yang lulus akan diberikan sertifikasi tanda kelulusan dan dapat dipergunakan sebagai syarat untuk pendaftaran perkawinan (Perdirjen Bimas Islam No DJ.II/542/2013 Pasal 
6). Selanjutnya akan dibahas seputar lembaga BP4.

\section{Profil KUA Pringsewu}

Kantor Urusan Agama (KUA) Kecamatan Pringsewu yang dahulu bernama Balai Nikah Kecamatan Pringsewu berkedudukan atau berkantor di gedung yang menempati tanah Pemda Kecamatan Pringsewu yang lokasinya bersebelahan dengan Pendopo Kecamatan Pringsewu. Namun ketika tanah Pemda dibangun, maka kantor KUA Pringsewu dipindahkan ke lokasi bangunan baru. Bangunan baru tersebut dibangun di atas tanah wakaf dari KH.Gholib yang berlokasi di jalan KH.Gholib pada tahun 1981.

Meskipun dikatakan bahwa kantor KUA Pringsewu ini pernah beberapa kali berberpindah-pindah kantor, namun Register Nikah (Akta Nikah) yang ada tetap tertata dan tersimpan dengan rapi sampai sekarang. Data Register Nikah yang paling awal penulis temukan semenjak tahun 1948. Dengan telah dibangunnya gedung KUA Pringsewu dan telah menempati gedung sendiri, maka kualitas dan kuantitas pelayanan kepada masyarakat terus berusaha untuk ditingkatkan. Gedung KUA berdiri di atas lahan tanah seluas 720 M2 dengan Luas Bangunan 142 M2 dan luas halaman 578 M2 sedangkan status tanahnya adalah tanah Negara (Pinjam Pakai tanah milik Pemerintah Daerah Kecamatan Pringsewu).

Dari tahun ke tahun sejak berdirinya, KUA Kecamatan Pringsewu mengalami peningkatan frekwensi pernikahan seiring dengan pertumbuhan dan perkembangan penduduk. KUA Kec. Pringsewu terus berkembang, apalagi seiring terbitnya KMA 477 Tahun 2004 tentang Pencatatan Nikah dan Peraturan Menteri Pendayagunaan Aparatur Negara Nomor: PER/62/M.PAN/6/2005 tentang Jabatan Fungsional Penghulu dan Angka Kreditnya, maka masingmasing KUA melaksanakan restrukturisasi sesuai acuan peraturan tersebut dengan struktur organisasi yang dipimpin oleh seorang Kepala, satu orang tenaga fungsional penghulu dan dibantu dua tenaga tata usaha dengan kualifikasi 
pendidikan dan persyaratan lain yang sesuai dengan standar tugasnya masing-masing.

Dalam bidang pelayanan, KUA Kecamatan Pringsewu memiliki 2 orang Penghulu dibantu oleh 13 Anggota Pembantu Pencatat Nikah (P3N) yang tersebar di 13 wilayah desa se-Kecamatan Pringsewu. Kantor Urusan Agama Kecamatan Pringsewu didukung oleh 4 pegawai yang terdiri dari 1 (satu) orang Kepala dan 1 (satu) orang Penghulu serta 4 (empat) orang Staf berstatus Pegawai Negeri Sipil dan 2 (dua) orang tenaga honorer yang dapat bekerja dalam bidang yang menjadi tugas dan wewenang KUA; satu orang sebagai tenaga administrasi/ tata usaha sedang yang lainnya bertugas sebagai penjaga kantor.

\section{Jumlah Peristiwa Nikah Rujuk di KUA Pringsewu}

Adapun statistik jumlah peristiwa Nikah dan Rujuk (NR) tahun $2011 \mathrm{~s} / \mathrm{d}$ 2015. Tahun 2011 jumlah pernikahan 846 dan tidak terdapat peristiwa rujuk. Tahun 2012 jumlah pernikahan 775 dan tidak terdapat peristiwa rujuk. Tahun 2013 jumlah pernikahan 680 dan tidak terdapat peristiwa rujuk. Tahun 2014 jumlah pernikahan 793 dan tidak terdapat peristiwa rujuk. Tahun 2015 jumlah pernikahan 333 dan tidak terdapat peristiwa rujuk. Walaupun pernikahan setiapnya menunjukkan grafik yang turun naik, tapi secara keseluruhan pernikahan di kecamatan dikatakan cukup tinggi. Data peristiwa nikah dan rujuk di KUA Pringsewu yang terjadi rentang 2011-2015 dapat disajikan dalam tabel berikut:

Tabel 1

Peristiwa Nikah dan Rujuk Di KUA Pringsewu

\begin{tabular}{|c|c|c|c|}
\hline No & Tahun & Nikah & Rujuk \\
\hline 1 & 2011 & 846 & - \\
\hline 2 & 2012 & 775 & - \\
\hline 3 & 2013 & 680 & - \\
\hline 4 & 2014 & 793 & - \\
\hline 5 & 2015 & 333 & - \\
\hline
\end{tabular}


(s/d Juni 2015)

\section{Pelaksanaan Kursus Pra Nikah di Kecamatan Pringsewu}

a. Subjek/Pelaksana Kursus Pra Nikah

Secara kelembagaan BP4 di kecamatan Pringsewu sudah terbentuk sesuai dengan SK BP4 Kecamatan Pringsewu No: 07/BP.4/Kab.Psw/IX/2013, berdasarkan SK tersebut regulasi penyelenggaraan Kursus Pra Nikah pada dasarnya harus dilaksanakan oleh BP4 akan tetapi kegiatan Kursus Pra Nikah dilaksanakan oleh pegawai KUA atau oleh anggota BP4 sendiri, seperti yang diungkapkan oleh Saiful Arfan bahwa pelaksana Kursus Pra Nikah itu dilaksanakan oleh siapa saja petugas yang ada di kantor, kadang oleh pegawai KUA bahkan jika ada anggota BP4 maka BP4 itu sendiri yang melaksanakan. ${ }^{9}$

b. Sarana dan Pembiayaan

Pelaksanaan Kursus Pra Nikah yang sudah berjalan sejauh ini, dipandang akan dapat terlaksana lebih baik lagi. Hal ini didukung dengan adanya regulasi yang sudah cukup, sarana tempat yang memadai, dan sumber daya manusia yang mumpuni.

Sarana penyelenggara kursus pra nikah meliputi sarana belajar mengajar: silabus, modul, dan bahan ajar lainnya yang dibutuhkan untuk pembelajaran. Silabus dan modul disiapkan oleh Kementerian Agama untuk dijadikan acuan oleh penyelenggara Kursus Pra Nikah. Hal ini sebagaimana diungkapkan oleh Kepala KUA Pringsewu; Saiful Arfan bahwa silabus, modul, dan bahan ajar yang digunakan pada Kursus Pra Nikah selama ini berasal dari Kementerian

9Saiful Arfan, Kepala KUA Kecamatan Pringsewu, Wawancara, Tanggal 22 Juni 2015

Pogram Pascasarjana UIN Raden Intan Lampung 
Agama. ${ }^{10}$ Silabus, modul, dan materi ajar yang disampaikan pada pelaksanaan Kursus Pra Nikah selama ini menggunakan silabus, modul, dan bahan ajar yang di dapatkan dari Kementerian Agama.

Sedangkan berkenaan dengan pembiayaan. Dengan regulasi yang sudah ada yaitu Perdirjen Bimas Islam Nomor : DJ.II/542 Tahun 2013 tentang Pedoman Penyelenggaraan Kursus Pra Nikah, dipandang sudah cukup untuk mengkover kegiatan Kursus Pra Nikah. Hanya saja untuk pelaksanaannya terdapat beberapa kendala. Pertama dalam hal pembiayaan masih tidak ada, karena alokasi anggaran sebagaimana yang diatur dalam Perdirjen tersebut baik yang berasal dari APBN ataupun APBD belum ada. Padahal pada pasal 5 disebutkan bahwa pembiayaan penyelenggaraan Kursus Pra Nikah dapat bersumber dari APBN dan APBD. ${ }^{11}$ Sedangkan pada bagian penjelasan pasal tersebut dikatakan bahwa: dana pemerintah berupa APBN atau APBD bisa diberikan kepada penyelenggara dalam bentuk bantuan. Bantuan kepada badan/ lembaga penyelenggara dapat dibenarkan sepanjang untuk peningkatan kesejahteraan dan pembinaan umat sesuai dengan peraturan perundangan yang berlaku, pemerintah dapat membantu badan/ lembaga swasta dari dana APBN/APBD. ${ }^{12}$

Sedangkan dalam Keputusan Dirjen Bimas Islam No: DJ.II/748 tahun 2014 disebutkan pada nomor (b) bahwa kegiatan Kursus Pra Nikah dihitung per peristiwa nikah sebesar Rp. 50.000,00 (lima puluh ribu rupiah). (c) Dana kegiatan Kursus Pra Nikah digunakan untuk pemberian honor dan atau transport nara sumber, pembelian konsumsi,

\footnotetext{
${ }^{10}$ Saiful Arfan, Kepala KUA Kecamatan Pringsewu, Wawancara, Tanggal 22 Juni 2015

${ }^{11}$ Direktorat Jenderal Pembinaan Kelembagaan Agama Islam, 2013, Op.Cit, h. 3

${ }^{12}$ Ibid, h. 14
} 
dan kelengkapan Kursus Pra Nikah. ${ }^{13}$

Sejak tahun 2013 sampai saat ini Kegiatan Kursus Pra Nikah ini tidak menggunakan biaya. Dan tentunya hal ini menjadi kendala karena pada pelaksanaannya. Kegiatan ini tidak dapat memberikan konsumsi bagi peserta dan sekaligus tidak dapat menghadirkan nara sumber dari luar atau lembaga lain untuk menyampaikan materi yang berhubungan dengan calon pengantin seperti: Kesehatan reproduksi, Kesehatan Ibu dan Anak, Undang-Undang KDRT dan ketentuan Pidana, dan lain-lainnya. ${ }^{14}$

\section{Sertifikasi Kursus Pra Nikah}

Pasal 6 Perdirjen Bimas Islam Nomor: DJ.II/542 Tahun 2013 tentang Pedoman Penyelenggaraan Kursus Pra Nikah menyebutkan bahwa: (a) Remaja usia nikah yang telah mengikuti Kursus Pra Nikah diberikan sertifikat sebagai tanda bukti kelulusan; (b) Sertifikat sebagaimana dimaksud pada ayat 1 dikeluarkan oleh BP4 atau organisasi keagamaan Islam penyelenggara kursus; (c) Sertifikat sebagaimana dimaksud pada ayat 1 dapat menjadi syarat kelengkapan pencatatan perkawinan; 15

Calon pengantin yang telah mengikuti Kursus Pra Nikah diberikan sertifikat sebagai tanda bukti kelulusan. Sertifikat tersebut akan menjadi syarat kelengkapan pencatatan perkawinan yaitu pada saat mendaftar di KUA Kecamatan, sekalipun dokumen sertifikat ini sifatnya tidak wajib tetapi sangat dianjurkan memilikinya, karena dengan memiliki sertifikat berarti pasangan pengantin sudah mempunyai bekal pengetahuan tentang kerumahtanggaaan dan berupaya mempersiapkan diri secara matang untuk

${ }^{13}$ Direktorat Jenderal Pembinaan Kelembagaan Agama Islam, Petunjuk Teknis Pengelolaan Penerimaan Negara bukan Pajak. Atas Biaya Nikah Atau Rujuk Di luar Kantor Urusan Agama Kecamatan, Jakarta: Direktorat Pembinaan Badan Peradilan Agama Islam, 2014, h. 10

${ }^{14}$ Saiful Arfan, Kepala KUA Kecamatan Pringsewu, Wawancara, Tanggal 22 Juni 2015

${ }^{15}$ Direktorat Jenderal Pembinaan Kelembagaan Agama Islam, Op.Cit, h. 3 
mengarungi kehidupan baru rumah tangga yaitu dengan membekali dirinya pengetahuan dan pemahaman tentang seluk beluk kerumahtanggaan, sehingga apapun goncangan yang mereka hadapi nantinya akan diantisipasi secara baik karena sudah dibekali rambu-rambunya.

Sertifikat dimaksud dikeluarkan oleh penyelenggara setelah peserta kursus dinyatakan lulus setelah selesai mengikuti Kursus Pra Nikah. Sertifikat yang dimaksud merupakan syarat pelengkap pencatatan perkawinan pada saat pendaftaran nikah di KUA Kecamatan. Berkenaan dengan sertifikasi kursus pra nikah di KUA Kecamatan Pringsewu merupakan syarat kelengkapan pencatatan nikah sebagaimana diungkapkan oleh Saiful Arfan menjelaskan bahwa menindaklanjuti surat BP4 Pusat No.059/13P/BP4/XII/2014 tanggal 16 Desember 2014 perihal Kursus Pra Nikah, dan Perdirjen Bimas Islam No: DJ.II/542/Tahun 2013 setiap calon pengantin yang mendaftarkan pernikahan di KUA harus mengikuti kursus pra nikah terlebih dahulu. ${ }^{16}$ Sertifikasi Kursus Pra Nikah menjadi salah satu syarat pencatatan nikah di KUA, oleh sebab itu tiap pasangan calon pengantin yang akan melangsungkan pernikahan seharusnya sudah mengikuti Kursus Pra Nikah.

\section{Peserta Kursus dan Materi Kursus}

Pada pasal 7 Perdirjen Bimas Islam Nomor : DJ.II/542 Tahun 2013 disebutkan bahwa peserta Kursus Pra Nikah adalah remaja usia nikah dan calon pengantin yang akan melangsungkan perkawinan. ${ }^{17}$

Penyelenggaraan Kursus Pra Nikah sebagaimana diatur dalam Perdirjen Perdirjen Bimas Islam Nomor : DJ.II/542 Tahun 2013 berbeda dengan kursus pra nikah yang telah dilaksanakan pada waktu yang lalu, kursus pra nikah biasanya dilakukan oleh KUA/BP4 kecamatan pada waktu

${ }^{16}$ Saiful Arfan, Kepala KUA Kecamatan Pringsewu, Wawancara, Tanggal

${ }^{17}$ Direktorat Jenderal Pembinaan Kelembagaan Agama Islam, Op.Cit, h. 3 
tertentu yaitu memanfaatkan 10 hari setelah mendaftar di KUA kecamatan sedangkan Kursus Pra Nikah lingkup dan waktunya lebih luas dengan memberi peluang kepada seluruh remaja atau pemuda usia nikah untuk mengikuti kursus tanpa dibatasi oleh waktu 10 hari setelah pendaftaran di KUA kecamatan. Sehingga para peserta kursus mempunyai kesempatan yang luas untuk dapat mengikuti Kursus Pra Nikah kapan pun mereka bisa mengikuti kegiatan tersebut sampai saatnya mendaftar di KUA kecamatan.

Saiful Arfan menjelaskan bahwa peserta Kursus Pra Nikah yang selama ini mendaftarkan diri kebanyakan adalah peserta yang akan melangsungkan pernikahan saja. ${ }^{18}$ Namun terdapat pula pasangan yang ingin melaksanakan pernikahan, namun mereka tidak mengikuti Kursus Pra Nikah ini.

Pasal 8 Perdirjen Perdirjen Bimas Islam Nomor : DJ.II/542 Tahun 2013 menyebutkan bahwa:

a. Materi Kursus Pra Nikah dibagi menjadi tiga kelompok, yaitu: Kelompok dasar, Kelompok Inti, dan Kelompok Penunjang.

b. Kursus Pra Nikah dilakukan dengan metode ceramah, diskusi, tanya jawab, dan penugasan yang pelaksanaannya disesuaikan dengan kondisi dan kebutuhan di lapangan.

c. Narasumber terdiri dari konsultan perkawinan dan keluarga, tokoh agama, dan tokoh masyarakat yang memiliki kompetensi sesuai dengan keahlian yang dimaksud pada ayat (1).

d. Materi Kursus Pra Nikah diberikan sekurangkurangnya 16 jam pelajaran. ${ }^{19}$

Materi-materi bimbingan yang diberikan kepada remaja secara umum adalah tentang :

a. Pengertian Nikah

${ }^{18}$ Saiful Arfan, Kepala KUA Kecamatan Pringsewu, Wawancara, Tanggal 22 Juni 2015

${ }^{19}$ Direktorat Jenderal Pembinaan Kelembagaan Agama Islam, Op.Cit, h. 3 
b. Hukum - Hukum Nikah

c. Tujuan Pernikahan

d. Memilih Jodoh

e. Syarat Dan Rukun Nikah

f. Larangan Perkawinan

g. Mahar Atau Mas kawin

h. Meminang

i. Walimah Atau Pesta Pernikahan

j. Hak dan Kewajiban Suami Istri

Sedangkan metode yang digunakan dalam pelaksanaan bimbingan adalah:

a. Metode caramah; digunakan untuk menyampaikan materi materi secara lisan.

b. Metode diskusi dan tanya jawab; digunakan untuk mengetahui sejauh mana penerimaan dan pemahaman materi yang disampaikan.

c. Metode demonstrasi; digunakan sebagai sarana dalam memberikan contoh.

Di KUA Kec. Pringsewu Pelaksanaan Kursus Pra Nikah bisa dilakukan pada hari kerja, tidak ditentukan harinya tetapi sesuai dengan kedatangan para calon pengantin di kantor KUA. Waktu pelaksanaan bimbingan Kursus Pra Nikah adalah kurang lebih selama 2 jam. Sedangkan materi yang diberikan meliputi: Figh Munakahat, UU Perkawinan No 1 Tahun 1974, Keluarga Sakinah, dan prosedur penikahan. Pematerinya terdiri atas: Kepala KUA, Penghulu, dan BP4. ${ }^{20}$

Berikut ini akan disajikan data tentang realitas pelaksanaan kegiatan Kursus Pra Nikah. Misalnya akan disajikan data pelaksanaan pernikahan dan dari pernikahan akan dilihat lebih lanjut berapakah pasangan yang mengikuti dan pasangan yang tidak mengikuti Kursus Pra Nikah di 22 Juni 2015

${ }^{20}$ Saiful Arfan, Kepala KUA Kecamatan Pringsewu, Wawancara,, Tanggal 
KUA Kec Pringsewu tahun 2014, terdapat 793 pernikahan, 555 di antara pasangan yang melangsungkan pernikahan tersebut mengikuti Kursus Pra Nikah (70\%). Sedangkan 238 pasangan $(30 \%)$ tidak mengikuti Kursus Pra Nikah.

\section{Implementasi Penyelenggaraan Kursus Pra Nikah di KUA Kecamatan Pringsewu}

Pelaksanaan Kursus Pra Nikah di Kantor Urusan Agama kecamatan Pringsewu telah melaksanakan kegiatan ini karena pelaksanaan kegiatan ini telah ada sebelum kebijakan Kursus Pra Nikah ini digulirkan. Meskipun berbeda nama, namun secara subsansial memiliki kesamaan. Dulu namanya Kursus Calon Pengantin (Suscatin), setelah keluarnya Perdirjen Bimas Islam Nomor: DJ.II/542 Tahun 2013 tentang Pedoman Penyelenggaraan Kursus Pra Nikah, maka namanya berubah menjadi Kursus Pra Nikah.

Perdirjen Bimas Islam Nomor: DJ.II/542 Tahun 2013 tentang Pedoman Penyelenggaraan Kursus Pra Nikah merupakan pedoman penyelenggaraan Kursus Pra Nikah. Sebagai pedoman untuk para pejabat teknis di lingkungan Direktorat Jenderal Bimbingan Masyarakat Islam c.q Direktorat Urusan Agama Islam di tingkat pusat, provinsi, Kecamatan/kota, dan KUA Kecamatan serta badan/lembaga yang menyelenggarakan kegiatan Kursus Pra nikah, meskipun pedoman ini telah dikeluarkan akan tetapi pada implementasinya masih banyak catatan. Baik catatan dari segi kelembagaan, pelaksana, sarana pra sarana, pembiayaan, peserta, dan materi kursus itu sendiri.

\section{a. Kelembagaan Kursus Pra Nikah}

Dalam pelaksanaannya, Kursus Pra Nikah ini tidak mengikat dalam melangsungan pernikahan. Tidak ada sanksi bagi yang tidak mengikutinya. Pasangan yang belum atau tidak mengikuti Kursus Pra Nikah tetap dapat melangsungkan pernikahannya. Kursus Pra Nikah bukan merupakan 


\section{4 ljtimaiyya: Jurnal Pengembangan Masyarakat Islam 10 (1) (2017)}

persyaratan yang harus dilalaui bagi mereka yang akan melangsungkan pernikahan.

Hal ini sejalan dengan pendapat Nasaruddin Umar yang menyatakan bahwa, kursus pra nikah bagi calon pengantin yang sekarang sifatnya masih sukarela, ke depan ada rencana untuk diregulasi. Nantinya calon pengantin baru bisa menikah setelah mendapat sertifikat kursus pra nikah. ${ }^{21}$

Ke depan, Kursus Pra Nikah harus bersifat wajib dan merupakan bahagian dari persyaratan pernikahan yang harus dilampirkan bersamaan dengan formulir N1, N2, N4, dan persyaratan wajib lainnya. Karena itu regulasinya tidak hanya sekedar Peraturan Dirjen tetapi harus dalam bentuk Peraturan Pemerintah atau minimal Keputusan Menteri Agama.

\section{b. Pelaksana Kursus Pra Nikah}

Dalam tataran pelaksanaannya, Kursus Pra Nikah tidak sepenuhnya dilaksanakan oleh pengurus BP4 kecamatan. Kenyataannya nara sumber Kursus Pra Nikah lebih banyak diambil alih oleh perangkat KUA setempat. Inilah yang ditegaskan oleh kepala KUA kec Pringsewu. Nara sumber Kursus Pra Nikah ini dalam pelaksanaannya diambil alih oleh Kepala KUA dan para penghulu dan pembantu penghulu saja. Kadang-kadang, jika ada saat pelaksanaan itu ada pengurus BP4, maka kemudian yang bersangkutanlah pelaksana Kursus Pra Nikah tersebut.

Masalah selanjutnya adalah walaupun dalam peraturannya dinyatakan bahwa nara sumber Kursus Pra Nikah itu adalah mereka yang ahli dalam masalah pernikahan sesuai dengan bidang keahliannya masing-masing seperti: dari tokoh agama, ahli di bidang kesehatan, BKKBN, dan tenaga ahli psikologi. Jika Kursus Pra Nikah itu hanya dilaksanakan oleh Kepala KUA, penghulu, ataupun pembantu penghulu tentulah belum atau tidak maksimal dalam penyampaian

${ }^{21}$ http://www.nu.or.id/ Antisipasi perceraian, Calon Pengantin harus Ikuti Kursus Pra Nikah -.diakses tangal 30 Juni 2015 
materi Kursus Pra Nikah tersebut. Keterbatasan Sumber daya manusia dilatarbekangi tidak tersedianya dana untuk dapat menghadirkan nara sumber yang berkompeten sesuai dengan bidang keahliannya masing-masing.

Adapun terkait dengan standardisasi ataupun sertifikasi nara sumber Kursus Pra Nikah ini, menurut penulis adalah agenda yang penting. Agar nara sumber yang berkualitas akan memberikan pemahaman para remaja dan mereka calon pengantin tentang pernikahan sesuai dengan keahlian mereka masing-masing. Pengetahuan yang memadai ini akan membekali peserta Kursus Pra Nikah dalam mengarungi kehidupan rumah tangganya nantinya. Pengetahuan itu akan menghantarkan mereka dalam mendapatkan sakinah dalam kehidupan rumah tangga mereka nantinya.

\section{c. Sarana Pra Sarana}

Dalam pelaksanaan Kursus Pra Nikah biasanya, sepenuhnya menggunakan fasilitas atau sarana pra sarana yang terdapat di KUA kecamatan setempat. Pelaksanaan Kursus Pra Nikah dilaksanakan di aula atau salah satu ruangan di KUA tersebut. Karena keterbatasan dana yang tersedia, pelaksanaan Kursus Pra Nikah hanya berimprovisasi dengan metode ceramah dan dialog. Pelaksanaan Kursus Pra Nikah miskin media dalam proses pembelajarannya. Tidak tersedia Laptop, LCD, bahkan mungkin sekedar pengeras suara, dan alat peraga lainnya.

Tentu saja pelaksanaan Kursus Pra Nikah dengan didukung oleh media pembelajaran seperti pengeras suara, laptop, LCD, dan alat peraga lainnya akan menghasilkan out put yang lebih baik. Karena media atau sarana pra sarana tersebut dapat mendukung, meningkatkan, dan menambah pemahaman peserta Kursus Pra Nikah terhadap materi kursus yang disampaikan oleh para nara sumber. Apalagi materi-materi seperti materi tentang kesehatan reproduksi, peraturan perundang-undangan seputar pernikahan, dan 
lainnya.

\section{d. Pembiayaan, Peserta, Waktu dan Materi}

Pembiayaan yang masih minim dalam pelaksanaan Kursus Pra Nikah, akan diuraikan lebih lanjut sebagai berikut:

a. Honorarium bagi nara sumber Kursus Pra Nikah. Dalam peraturannya terdapat honorarium bagi nara sumber Kursus Pra Nikah yang nominalnya Rp 50.000/ pasangan. Honorarium itupun dalam kenyataannya cair baru akhir tahun 2015 walaupun peraturannya sudah ditetapkan sejak 2013. Priode sebelumnya, nara sumber Kursus Pra Nikah itu tidak dibayar alias gratis. Kalaupun ada, biasanya merupakan pemberian dari pesertanya.

b. Kondisi tersebut berdampak pada pelaksanaan Kursus Pra Nikah itu sendiri. BP4 sebagai lembaga yang mendapat amanah dan mandat melaksanakan Kursus Pra Nikah ini tidak dapat melaksanakan tugas mereka dengan baik dan maksimal. Mungkin kesibukan dalam mencari nafkah untuk keluarga, menyebabkan mereka tidak bisa menunaikan tugasnya sebagai BP4 dalam memberikan Kursus Pra Nikah.

c. Selain masalah itu masalah pembiayaan ini juga berdampak pada penyediaan sarana pra sarana dan konsumsi saat pelaksanaan Kursus Pra Nikah. Sebagaimana dijelaskan sebelumnya, bahwa pelaksanaan Kursus Pra Nikah hanya memanfaatkan sarana prasarana milik KUA setempat.

d. Mendatangkan nara sumber Kursus Pra Nikah yang expert di bidangnya masing-masing. Mendatangkan mereka berharap hasil Kursus Pra Nikah yang lebih maksimal, akan terhadang oleh permasalahan ketersediaan dana untuk membayar honorarim mereka. Sehingga akhirnya Kursus Pra Nikah hanya diisi oleh anggota BP4 atau para aparat KUA. 
Pelaksanaan Kursus Pra Nikah di Kecamatan Pringsewu ternyata hanya diikuti oleh remaja putra putri yang akan segera memasuki jenjang pernikahan saja, tidak terdapat peserta Kursus Pra Nikah dari remaja yang belum akan melangsungkan pernikahan; mereka yang dengan kesadarannya sendiri menyiapkan diri berupa wawasan dan pengetahuan tentang kehidupan berumah tangga dengan mengikuti Kursus Pra Nikah. Hal ini mungkin karena faktor pemahaman umum di tengah-tengah masyarakat bahwa Kursus Pra Nikah itu hanya diperuntukkan untuk mereka yang akan segera memasuki jenjang pernikahan.

Tragisnya, temuan di lapangan bahwa data pelaksanaan pernikahan dan pasangan yang tidak mengikuti Kursus Pra Nikah di KUA Kec Pringsewu pada tahun 2014 terdapat 793 pernikahan, 555 di antara pasangan yang melangsungkan pernikahan tersebut mengikuti Kursus Pra Nikah (70\%). Sedangkan 238 pasangan (30\%) tidak mengikuti Kursus Pra Nikah.

Materi Kursus Pra Nikah telah distandarisasikan dengan 7 materi selama 24 jam pelajaran. Dari sisi waktu pelaksanaan ternyata masih belum maksimal. Kantor Urusan Agama yang melaksanakan kursus pra nikah hanya satu atau dua jam saja dengan tuntutan materi yang begitu banyak.

Materi Kursus Pra Nikah biasanya hanya fokus pada aspek hukum Islam dari masalah pernikahan. Adapun aspekaspek lainnya mungkin dijelaskan sekedar pengetahuan yang mereka miliki.

Kondisi ini menyebabkan para peserta Kursus Pra Nikah tidak mendapatkan pemahaman yang utuh tentang materi-materi Kursus Pra Nikah yang seharusnya mereka peroleh setelah mengikuti kursus. Hal ini mungkin kurang atau tidak memadai sebagai bekal mereka dalam menghadapi permasalahan saat menempuh atau mengharungi kehidupan rumah tangga mereka nantinya.

\section{Dampak Penyelenggaraan Kursus Pra Nikah}


Berdasarkan deskripsi di atas jelas bahwa dari sisi kebijakan sebenarnya telah ada upaya dari pemerintah untuk mewujudkan kehidupan rumah tangga yang sakinah masyarakatnya. Yakni dengan dikeluarkannya aturan tentang Kursus pra nikah. Banyak penelitian menggambarkan bahwa ada keterkatian yang erat antara pemahaman, pengetahuan seseorang tentang pernikahan dengan cara mereka menyikapi persoalan kehidupan keluarga, layanan bimbingan dengan orientasi persiapan pernikahan, dan hidup berkeluarga sangat mempengaruhi sikap seseorang dalam memandang pernikahannya. Karena itu dibutuhkan layanan bimbingan dan konseling pernikahan untuk membantu seseorang agar siap menjalani kehidupan pernikahan sehingga nantinya mampu menciptakan keluarga yang harmonis.

Selanjutnya akan dilihat lebih lanjut data tentang perceraian yang terjadi di Kecamatan Pringsewu. Kecamatan belum memiliki Pengadilan Agama yang mandiri. Masyarakat Kecamatan Pringsewu dalam beperkara, menginduk ke Pengadilan Agama Tanggamus. Ketika penulis mencari data tentang perceraian masyarakat Kecamatan Pringsewu, khususnya kecamatan Pringsewu data yang tersedia masih bersifat global-berupa data berupa buku register. Lalu penulis memilah data tersebut satu persatu, sehingga kemudian terkumpullah data-data yang dibutuhkan.

Penulis telah berupaya menginventaris data-data peristiwa perceraian dikaitkan dengan pelaksanaan Kursus Pra Nikah dari kecamatan Pringsewu dari tahun 2013-2015; yakni saat penelitian ini dilaksanakan.

Selanjutnya akan disajikan data yang akan dianalisa adalah dari tahun 2013-2015 untuk semua kecamatan tersebut.

Data-data tersebut dapat disajikan sebagai berikut: Total perceraian yang terjadi tahun 2013 pada tiga kecamatan tersebut adalah 147 kasus. Dari kasus-kasus tersebut, akan diuraikan berdasarkan asal kecamatannya. Pada kecamatan Pringsewu tahun 2013 terjadi 80 kasus perceraian 78 dari 
kasus tersebut, mereka yang menikah sebelum bulan Juli tahun 2013 saat peraturan Kursus Pra Nikah diberlakukan. Adapun mereka yang bercerai dan menikah setelah peraturan Kursus Pra Nikah diberlakukan terdiri dari nihil mereka yang ikut Kursus Pra Nikah sebelumnya dan 2 orang, mereka yang tidak ikut Kursus Pra Nikah.

Pada kecamatan Pringsewu tahun 2014 terjadi 89 kasus perceraian 86 dari kasus tersebut, mereka yang menikah sebelum bulan Juli tahun 2013 saat peraturan Kursus Pra Nikah diberlakukan. Adapun mereka yang bercerai dan menikah setelah peraturan Kursus Pra Nikah diberlakukan terdiri dari nihil mereka yang ikut Kursus Pra Nikah sebelumnya dan 3 orang, mereka yang tidak ikut Kursus Pra Nikah.

Pada kecamatan Pringsewu tahun 2015 terjadi 63 kasus perceraian 58 dari kasus tersebut, mereka yang menikah sebelum bulan Juli tahun 2013 saat peraturan Kursus Pra Nikah diberlakukan. Adapun mereka yang bercerai dan menikah setelah peraturan Kursus Pra Nikah diberlakukan terdiri dari nihil mereka yang ikut Kursus Pra Nikah sebelumnya dan 5 orang, mereka yang tidak ikut Kursus Pra Nikah.

Pembacaan dari tabel di atas dapat dijelaskan sebagai berikut:

a. Dari kasus-kasus perceraian yang terjadi pada tahun 2013-2015 di kecamatan Pringsewu didominasi oleh pasangan yang menikah sebelum peraturan Kursus Pra Nikah digulirkan.

b. Secara umum data tingkat perceraian mereka yang tidak Kursus Pra Nikah lebih tinggi pada ketiga kecamatan tersebut pada tahun 2013-2015 dibandingkan dengan mereka yang mengikuti Kursus Pra Nikah.

c. Berdasarkan data di atas, dapat digarisbawahi bahwa pelaksanaan Kursus Pra Nikah di kecamatan Pringsewu memiliki andil dalam menekan tingkat angka perceraian di ketiga kecamatan tersebut. Serta tentu saja 
120 ljtimaiyya: Jurnal Pengembangan Masyarakat Islam 10 (1) (2017)

mendorong terbentuknya keluarga yang sakinah.

\section{Kesimpulan}

Berdasarkan hasil penelitian di atas dapat disimpulkan sebagi berikut :

1. Penyelenggaraan Kursus Pra Nikah di Kecamatan Pringsewu masih kurang atau tidak optimal; baik dari segi kelembagaan, pelaksana atau nara sumber, sarana pra sarana, pembiayaan, peserta, dan materi kursus.

2. Kebijakan tentang Kursus Pra Nikah Kecamatan Pringsewu memiliki andil dalam menekan tingkat angka perceraian, serta mendorong terbentuknya keluarga yang sakinah di daerah tersebut.

\section{Daftar Pustaka}

Direktorat Jenderal Pembinaan Kelembagaan Agama Islam, Petunjuk Teknis Pengelolaan Penerimaan Negara bukan Pajak Atas Biaya Nikah Atau Rujuk Di luar Kantor Urusan Agama Kecamatan, Jakarta: Direktorat Pembinaan Badan Peradilan Agama Islam, 2014

Ghazaly, Abd Rahman, Fikih munakahat, Jakarta: Kencana Prenada Media Grup, 2003

Hasil Putusan MUNAS BP4 ke XIV/2009, Jakarta, 1-3 Juni 2009

http://www.nu.or.id/ Antisipasi perceraian, Calon Pengantin harus Ikuti Kursus Pra Nikah -.diakses tangal 30 Juni 2015

Peraturan Direktur Jenderal Bimbingan Masyarakat Islam Nomor DJ.II/542 TAHUN 2013 tentang Pedoman Penyelenggaraan Kursus Pra Nikah, Jakarta, 2013

Tim Redaksi Kamus Pusat bahasa, Kamus Besar Bahasa Indonesia, Jakarta: Balai Pustaka, 2007

Wawancara dengan Saiful Arfan, Kepala KUA Kecamatan Pringsewu, Tgl 22 Juni 2015 